\title{
ANALYSIS OF STUDENT ERRORS IN COMPLETING SIGNIFICANT FIGURES PROBLEMS
}

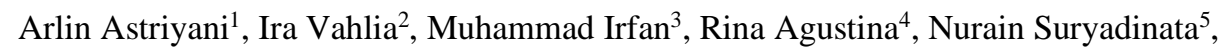 \\ Satrio Wicaksono ${ }^{6}$ \\ \{arlinastri07@gmail.com¹, iravahlia768@yahoo.co.id ${ }^{2}$, muhammad.irfan@ustjogja.ac.id ${ }^{3}$, \\ aasyiqun1212@gmail.com ${ }^{4}$, nurain.suryadinata@gmail.com ${ }^{5}$,rio_sudarman@yahoo.com $\left.{ }^{6}\right\}$ \\ Pendidikan Matematika, Universitas Muhammadiyah Jakarta ${ }^{1}$, Pendidikan Matematika, Universitas \\ Muhammadiyah Metro Lampung ${ }^{2,4,5,6}$, Pendidikan Matematika, Universitas Sarjanawiyata Tamansiswa ${ }^{3}$
}

\begin{abstract}
The purpose of this study was to determine errors when solving problems related to significant figures. This research is descriptive qualitative research. The subject of this study was the odd semester student of Muhammadiyah University of Jakarta mathematics education 2018/2019 academic year consisting of 3 students. Data collection techniques used in this study are interviews, documentation and observation. The results showed that the percentage of concept errors in the three subjects was $38.09 \%$ while the operating error was $83.33 \%$. Based on the results of the interview, the cause of the three subjects made a mistake, namely the lack of time in working on the questions, lack of thoroughness in working on the questions, lack of mastering the concepts and miscalculation.
\end{abstract}

Keywords: mistake, significant figures.

\section{Introduction}

Mathematics is one of the subjects that are familiar to us. Counting is no activity of daily activities without using mathematics. Mathematics develops the ability to calculate, measure, derive and use mathematical formulas needed in everyday life through measurement and geometry, algebra, opportunities and statistics, calculus and trigonometry. Mathematics also develops the ability to communicate ideas through mathematical models that can be mathematical sentences and mathematical equations, diagrams, graphs or tables.

Many efforts can be made to improve the quality of education, including curriculum renewal, teaching and learning processes, improving the quality of teaching staff, procurement of textbooks, teaching and learning facilities, improvement of assessment systems and so on. The level of success of teaching and learning is influenced by many factors including the ability of the teaching force, the basic abilities of students, learning approaches, materials, infrastructure, motivation, creativity, discipline, evaluation tools and the environment which are all one of the most related units that work in an integrated manner to achieve goals that has been set [1]. Even though the objectives are well formulated, the material chosen is appropriate, if the learning approach used is not in accordance with the main material given to students, it allows the goals that are expected not to be well achieved. 
Based on the facts in the field, some students did not understand the rules of significant figures. This is seen when the researcher gives questions related to significant figures. The existence of barriers experienced by students when learning can be known by the mistakes made. These obstacles may be realized or maybe not realized in the process of achieving their learning outcomes. As a result, the achievements he achieved were below what they should be. The rules of significant figures are as follows: (1) All non-zero numbers are significant figures; (2) All zeros located between non-zero numbers include significant figures; (3) In decimal numbers $<1$, zeros on the right or left of the decimal point do not include significant figures; (4) In decimal numbers $\geq 1$, the zeros located at the end of the number include significant figures; (5) If in a number there is a number that is underlined as the estimated price, the calculation of significant figures ends in the underlined number.

Errors arise due to the difficulties of students in learning. A child who has difficulty in learning will show the characteristics of the problems experienced, as follows: (1) Shows learning outcomes that are lower (below the average value) achieved by the group; (2) The results achieved are not balanced with the effort that he does; (3) Slow in carrying out their learning tasks; (4) Demonstrating unfair attitudes; (5) Demonstrate behaviors with disabilities and; (6) Shows less emotional symptoms [2].

According to the Big Indonesian Dictionary, mistakes are wrong; mistake; negligence, so that if the error is related to the basic object of mathematics [2], the error in question is: (1) Error of fact is a mistake in writing conventions expressed by mathematical symbols. Example: errors in changing problems into mathematical models, errors in interpreting the results obtained and errors in writing mathematical symbols; (2) Misconception is a mistake in classifying or classifying a set of objects. The concept referred to in mathematics can be in the form of a definition. Example: an error in classifying a relation, whether it is a function or not; (3) Operating errors are errors in calculating work, algebraic work, and other mathematical works. Examples: errors in adding up, subtracting, and errors in other mathematical operations; (4) The principle error is the mistake in relating some facts or some concepts. Example: errors in using formulas or theorems and errors in using previous principles. Mistakes often experienced by students include: (1) errors in writing mathematical symbols; (2) the meaning of mathematical models, and (3) inconsistencies in the use of symbols [4]

The types of student errors that are often carried out are errors in abstraction, concept, computation and interpretation [4]. The factors behind students make mistakes. Factors that can lead to student learning difficulties are classified into two, namely: a) factors derived from students themselves (internal factors), b) factors that are outside (external factors) [6]. students do not understand the problem at hand [5] and are unable to choose the right strategy to solve the problem [8].

Research related to the above problems, students' errors in solving story problems [9]. The results of the study show that the types of errors that the subject does are conceptual errors that include errors in understanding the concept of rectangles, the concept of broad squares, and the concept of rectangular sides. Principal errors and operations cannot be investigated further because the subject made a mistake in translating the question into a mathematical model, so that the subject cannot perform the next stage of completion correctly.

Other related researches who examine students' errors in solving social arithmetic story problems [10]. The results The results showed the types of errors made by students were concepts $(37.73 \%)$, principles $(50 \%)$ and techniques $(31.18 \%)$. Based on the results of the interview data analysis obtained several factors that cause students to make mistakes, among others: students are hasty in answering questions, students are not ready to undergo the test or in other words students do not learn before the test, students do not understand the purpose of 
the problem, students do not master the concept related to test questions. While the findings from [7]: (1) do not understand the use of variables, (2) do not understand the use of formulas, (3) do not understand the key phrases on the problem, (4) Difference in ratio , fractional, and division, (5) do not understand the problem, (6) do not understand proportional division, and (7) do not interpret proportionation correctly.

Based on the above problems, the purpose of this study was to determine errors when solving problems related to significant figures.

\section{RESEARCH METHODS}

This type of research is descriptive qualitative. The subject of this study was a Muhammadiyah University of Jakarta mathematics education student in the odd semester of 2018/2019 school year consisting of 3 students where the subject was chosen based on errors in solving problems about significant figures and rounding. Qualitative data is obtained based on the results of interviews with the subject, documentation of the subject's work. Questions related to significant figures, namely:

Table 1. Questions related to significant figures.

\begin{tabular}{ll}
\hline No & Question \\
\hline 1 & What are the significant figures in the following numbers. \\
a. 1,237698 \\
b. 0,000500 \\
c. 1,7000 \\
d. 5,0007 \\
e. 1309787 \\
The length of the rope measured by a student is $0.20350 \mathrm{~m}$. The \\
number of significant figures of the measurement results is ... \\
The result of measuring the length of an object is $0.02030 \mathrm{~m}$. These \\
measurement results have as many significant figures ... \\
Based on the rules of significant figures, calculate \\
a. $3.24+0.2$ \\
b. $4,75-1,8$
\end{tabular}

Data analysis in qualitative research consists of three components, namely (1) Data reduction which is the process of selection, focusing, simplification and abstraction of fieldnotes data. This process continues throughout the course of research, (2) Data presentation is an assembly of information organizations, descriptions in the form of narratives that allow research to be carried out, (3) drawing conclusions and verification because basically the meaning of the data must be tested (verified) validity so that the research conclusions become more sturdy and more reliable. 


\section{RESULT AND DISCUSSION}

Data obtained from the results of the work of the subjects in resolving the problems of significant figures, including:

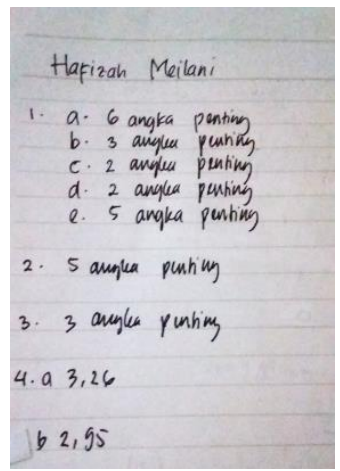

Fig. 1. Subject A. Answer

In subject $\mathrm{A}$, an error is made in completing

1. Problem number $1 \mathrm{c}$ that is about rule 4 about decimal number $\geq 1$, the zero number that is located at the end of the number includes significant figures. The correct answer to problem number $1 \mathrm{c}$ is 5 significant figures.

2. Problem number 1d, All zeros located between non-zero numbers include significant figures. The correct answer is 5 significant figures.

3. Problem number 3 , which is about the combination of rule 2 , rule 3 and rule 4 . The correct answer to problem number 3 is 4 significant figures.

4. Problem number $4 \mathrm{a}$ and $4 \mathrm{~b}$ are about addition and subtraction using the rules of significant figures. The correct answer to problem number $4 \mathrm{a}$ is 3.4 and the correct answer to problem number $4 \mathrm{~b}$ is 3.0 .

Subject A made a misconception is a mistake in classifying or classifying a set of objects in problem number $1 \mathrm{c}$ which uses rules 4 , 1d which use rules 2 and number 3 which use rule 2 , rule 3 and rule 4 and operating errors in calculations number $4 \mathrm{a}$ and $4 \mathrm{~b}$ concerning addition and subtraction using significant figures.

Data obtained from the results of the work of the subjects in resolving the problems of significant figures, including:

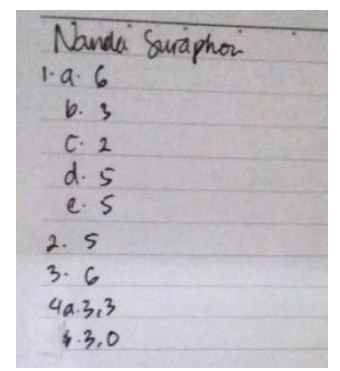

Fig. 1. Subject B. Answer 
On subject $\mathrm{B}$, an error is made in completing

1. Problem number $1 \mathrm{c}$, which is about rule 4 , that is at decimal number $\geq 1$, the zero number that is located at the end of the number includes significant figures. The correct answer to problem number $1 \mathrm{c}$ is 5 significant figures.

2. Problem number 3 is about the combination of rules, rule 3 and rule 4 about decimal number $<1$. The correct answer to problem number 3 is 4 significant figures.

3. Problem number $4 \mathrm{a}$ is about addition and subtraction using the rules of significant figures. The correct answer to problem number $4 \mathrm{a}$ is 3.4 .

Subject B made a misconception is a mistake in classifying or classifying a set of objects in problem number $1 \mathrm{c}$ that uses rule 4 , number 3 which uses rule 2 , rule 3 and rule 4 and operating errors in calculation number $4 \mathrm{a}$ concerning addition and subtraction using significant figures .

Data obtained from the results of the work of the subjects in resolving the problems of significant figures, including:

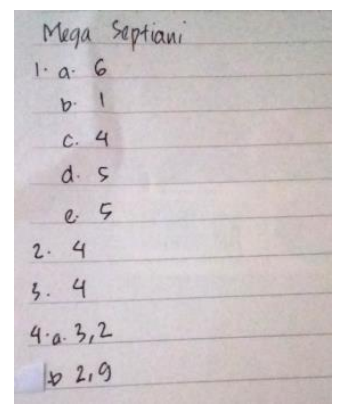

Fig. 1. Subject C. Answer

On subject $\mathrm{C}$, an error is made in completing

1. Problem number $1 \mathrm{~b}$ regarding rule 3 , in decimal numbers $<1$, zeros on the right or left of the decimal point do not include significant figures. The correct answer is 3 significant figures.

2. Problem number $1 \mathrm{c}$ is about rule 4 that is at decimal number $\geq 1$, the zero number that is located at the end of the number includes significant figures. The correct answer to problem number 1c is 5 significant figures.

3. Problem number 2, which is about the combination of rule 2, rule 3 and rule 4 . The correct answer is 5 significant figures.

4. Questions number $4 \mathrm{a}$ and $4 \mathrm{~b}$ are about addition and subtraction using the rules of significant figures. The correct answer to problem number $4 \mathrm{a}$ is 3.4 and the correct answer to problem number $4 \mathrm{~b}$ is 3.0 .

Subject $\mathrm{C}$ made a misconception is a mistake in classifying or classifying a set of objects in problem number $1 \mathrm{~b}$ that uses rule 3 , number $1 \mathrm{c}$ which uses rules 4 and number 2 which uses rule 2, rule 3 and rule 4 and operating errors in calculations number $4 \mathrm{a}$ and $4 \mathrm{~b}$ regarding addition and subtraction using significant figures.

The questions were given to the subjects of 3 students. Based on the results of problem solving, subjects A, B and C made mistakes in working on questions related to rules 2.3 and 4 . It's just that subject $B$ has fewer errors than the other two subjects. This can be seen from subject B who made 3 errors while subject A and B 5 made mistakes. Errors made by the three 
subjects are conceptual errors where errors occur in classifying or classifying a set of objects. The concept referred to in mathematics can be in the form of a definition. This can be seen from the answers of the three subjects who still lack understanding about the rules of significant figures especially related to the number 0 in rules 2, 3 and 4 . While another error is about operating errors, where errors occur in adding, subtracting, and errors in mathematical operations others.

\section{CONCLUSIONS}

Based on the research that has been done it can be concluded that the mistakes made by the three subjects are conceptual errors in which there is a mistake in classifying or classifying a set of objects. The concept referred to in mathematics can be in the form of a definition. This can be seen from the answers of the three subjects who still lack understanding about the rules of significant figures especially related to the number 0 in rules 2,3 and 4 . The percentage of concept errors in the three subjects is $38.09 \%$. While another error is about operating errors, where errors occur in adding, subtracting, and errors in other mathematical operations. The percentage of operating errors is $83.33 \%$. Based on the results of the interview, the cause of the three subjects made a mistake is the lack of time, lack of thoroughness in working on the problem, lack of mastering the concept and miscalculation.

\section{References}

[1] Aly, Siti Munjiyatun. 2009. Pengaruh Model Pembelajarn Kooperatif Tipe Students Teams Achievement Division (STAD) dan Group Investigation (GI) terhadap Prestasi Belajar Matematika Ditinjau dari Kreativitas Peserta didik. Tesis. Tidak Diterbitkan. Surakarta: UNS.

[2] Muhkal, Mappaita. Pengaruh Konsep Diri Matematika dan Motivasi Berprestasi terhadap Prestasi Belajar Matematika Peserta didik Kelas I SMU Negeri Kotamadya Ujung Pandang. Malang: Direktorat Jenderal Pendidikan Tinggi (2013)

[3] Soedjadi, R. Kiat pendidikan matematika di Indonesia : konstatasi keadaan masa kini menuju harapan masa depan. Jakarta: Direktorat Jenderal Pendidikan Tinggi (2000)

[4] Irfan, Muhammad. "Analisis Kesalahan Siswa dalam Pemecahan Masalah Berdasarkan Kecemasan Belajar Matematika." Kreano, Jurnal Matematika Kreatif-Inovatif 8.2 (2017).

[5] Sulistyorini. (2010). Analisis Kesalahan Siswa Kelas X-5 Negeri 1 Sooko Mojokerto Dalam Menyelesaikan Soal Cerita Materi Program Linier. Surabaya: Unesa

[6] Hamalik, Oemar. (2005). Kurikulum dan Pembelajaran.Jakarta: Bumi Aksara.

[7] Irfan, Muhammad, et al. "WHY DID THE STUDENTS MAKE MISTAKES IN SOLVING DIRECT AND INVERSE PROPORTION PROBLEM?." International Journal of Insights for Mathematics Teaching (IJOIMT) 1.1 (2018).

[8] Irfan, M., and R. Rahardi. "Characteristics of students in comparative problem solving." Journal of Physics: Conference Series. Vol. 948. No. 1. IOP Publishing, 2018.

[9] Rahmania, Listia dan Rahmawati, Ana. 2016. Analisis Kesalahan Siswa dalam Menyelesaikan Soal Cerita Persamaan Linier Satu Variabel. JMPM: Jurnal Matematika dan Pendidikan Matematika. Vol. 1, No. 2.

[10] Astutik, Yuni dan Lambang, Kurniawan. 2015. Kesalahan Siswa Dalam Menyelesaikan Soal Cerita Aritmatika Sosial. Jurnal Pendidikan Matematika STKIP PGRI Sidoarjo. Vol. 3. No.1

Hardiyansyah. 2016. Teori Indikator Kualitas Pelayanan Publik. Online. http://www.materibelajar.id/2016/10/contoh-format-pedoman-wawancara.html, (diakses tanggal 1 September 2018) 